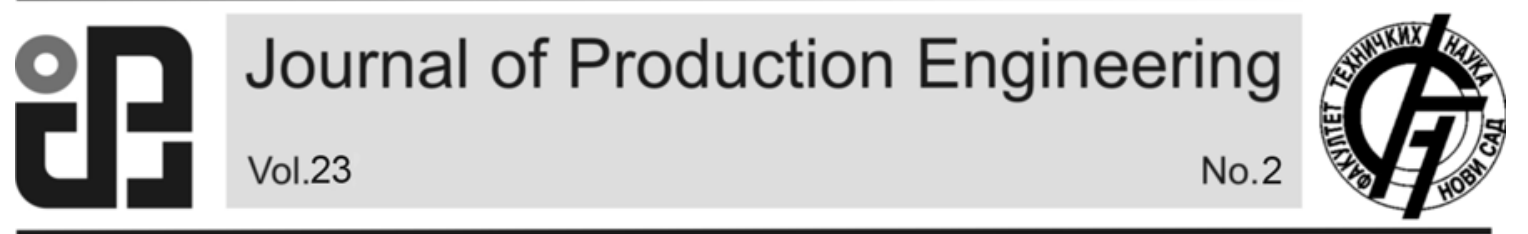

JPE (2020) Vol.23 (2)

Mehra V., Gupta, V., Khanna, P.

Original Scientific Paper

\title{
MATHEMATICAL MODELLING TO PREDICT ANGULAR DISTORTION IN MIG WELDING OF STAINLESS STEEL 202 PLATES
}

Received: 18 May 2020 / Accepted: 24 September 2020

\begin{abstract}
In present research, mathematical models have been established to predict the angular distortion in Metal Inert Gas(MIG) welding for $6 \mathrm{~mm}$ plates of SS 202 grade for butt welded joints. The filler metal used was a continuously fed solid metal wire of stainless steel (304L).100\% Argon gas was used to serve the purpose of shielding the weld pool from the atmosphere as it does not dissociate at high temperatures. This prevented any turbulence in the welding arc and deterioration in weld quality. To obtain experimental samples, the design matrix was developed using the statistical technique of central composite rotatable design (CCRD). Analysis of Variance (ANOVA) technique was used for the adequacy check of the models developed. The models developed can be used to find direct and interaction effect of the input parameters, namely welding speed (WS), voltage (V), nozzle to plate distance (NPD), torch angle $(\theta)$ and wire feed rate (WFR) on the angular distortion.
\end{abstract}

Key words: Stainless Steel Grade 202, MIG Welding, CCRD, ANOVA, Response Surface Methodology, F-ratio ANOVA.

Matematičko modeliranje u cilju predviđanja ugaonih izobličenja pri MIG zavarivanju ploča od nerđajućeg čelika 202. U sadašnjim istraživanjima uspostavljeni su matematički modeli za predviđanje ugaonih izobličenja pri MIG postupku zavarivanja metalih ploča od nerđajućeg čelika, debljine 6mm. Kao dopunski materijal korišćena je neprekidno punjena metalna žica od nerđajućeg čelika (304L). 100\% gas argon korišćen je u svrhu zaštite zone zavarivanja od atmosfere, jer se ne razgrađuje pri visokim temperaturama. Ovo je sprečilo bilo kakve turbulencije u luku za zavarivanje i pogoršanje kvaliteta zavara. Da bi se dobili eksperimentalni uzorci, dizajnirana je matrica dizajna koristeći statističku tehniku centralnog kompozitnog dizajna eksperimenta (CCRD). Za proveru adekvatnosti razvijenih modela korišćena je tehnika analize varijanse (ANOVA). Razvijeni modeli mogu se koristiti za pronalaženje direktnog i interakcionog efekta ulaznih parametara na izobličenja ugla zavra. Ulazni faktori čiji se ekekat ispitiao bili su: brzina zavarivanja (WS), napon (V), udaljenost mlaznice do ploče (NPD), ugao gorionika ( $\theta$ ) i brzina dodavanja žice (VFR).

Ključne reči: Nerđajući čelik klase 202, MIG zavarivanje, CCRD, ANOVA, Metodologija odzivne površine, F-odnos ANOVA.

\section{INTRODUCTION}

Stainless Steel 202 is an austenitic grade steel having exceptional resistance to corrosion even in adverse environments, making it suitable for the manufacturing of components which come in contact with reactive chemicals and gases, such as the exhausts of vehicles, material handling equipment in industries, structural components, chemical storage tanks etc. [1]. The composition of the steel and its mechanical properties are represented in Table 1 and 2 respectively. Angular distortion is a very frequent defect in fusion welding [2]. A number of factors have a considerably understood effect on the angular distortion. Thickness of the plate as well as the heat energy have a prominent effect on this distortion [3]. The percentage of carbon dioxide in the shielding gas increases this defect for welding stainless steel [4]. Pre-compression stress in the transversal direction increases welding angular distortion by up to 2.5 times [5].

When the weld pool forms during welding, due to its extremely high temperature compared to the room, thermal expansion takes place, which compresses the base plate near the heat affected zone, causing it to deform plastically, called the plastic deformation zone (PDZ). The weld pool finally cools down and thermal contraction takes place. However, the material in the deformation zone had been compressed before, which has to be stretched in a reverse direction for the shrinkage of weld metal [6]. The PDZ applies a tensile force to the weld pool and prevents it free contraction. Thus, forces generate between the weld pool and the base plate. These forces provide a bending moment to the base plate. If no external fixtures are used to hold the base plates, the bending moment causes the base plates to lift up, resulting in angular distortion; whereas, if fixtures are provided, instead of an angular distortion, residual stresses will be formed which is even more dangerous. If one is able to predict the angular distortion for a given set of parameters, the distortion can be prevented by offsetting the plates in the opposite direction of forthcoming distortion, thereby negating the effect. In the current work, CCRD technique was used to develop the design matrix for conducting the experiment. ANOVA technique has been used to check the adequacy of the equations developed [7].

Fig.1 shows angular distortion between the two base plates. 


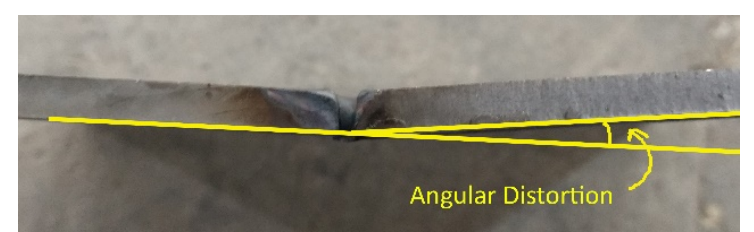

Fig. 1. Angular Distortion

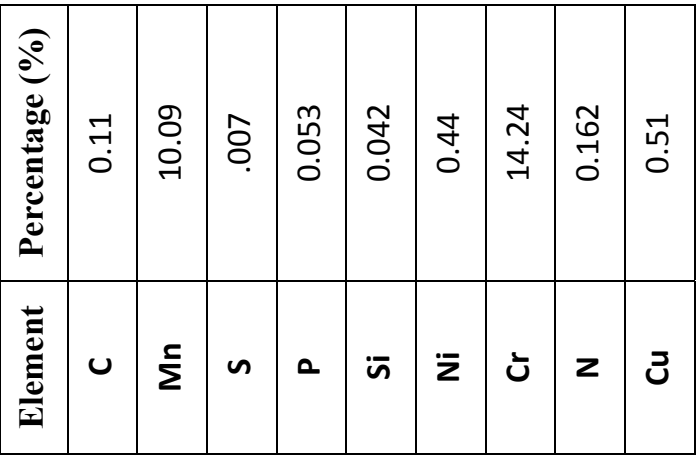

Table 1. Chemical Composition

\begin{tabular}{|l|l|}
\hline Grade & 202 \\
\hline Mechanical Properties & ASTM A240 \\
\hline Ultimate Tensile Strength (MPa) & $\geq 620$ \\
\hline Yield Strength (MPa) & $\geq 260$ \\
\hline \% Elongation & $\geq 40$ \\
\hline Hardness (HRB) & $\leq 241$ \\
\hline
\end{tabular}

Table 2. Mechanical Properties

\section{WORKING SETUP}

The working setup used in the current investigation consisted of a MIG welding power source of rectifier type with open circuit voltage of 45 Volts and rated current capacity of 400 amperes. The source had 100\% duty cycle and with flat V-I Characteristics. For shielding, $100 \%$ industrial Ar Gas was used at a volumetric rate of 15 liters/ min, being maintained throughout the experiment. A mechanized welding unit was used to maintain the desired welding speed and ensure reproducibility of results, which provided with a step-less control of carriage speed from 0 to $50 \mathrm{~cm} / \mathrm{min}$. A VFD was used to change the speed of carriage motor.
The complete setup is shown in Fig. 2.

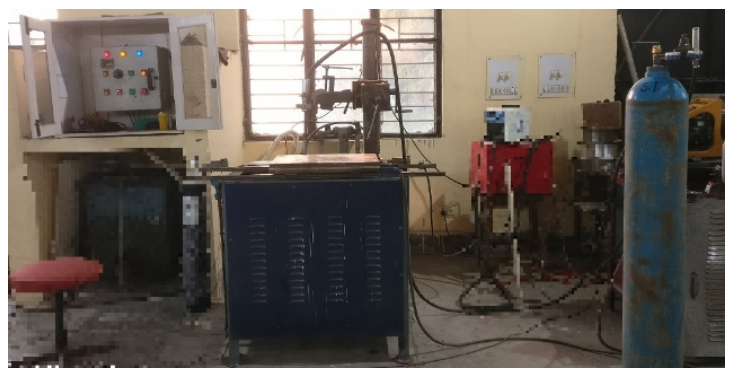

Fig. 2. Experimental Set-up

\section{PLAN OF INVESTIGATION-}

The current investigative work was carried out in the following steps:

1. Identification of input parameters and determination of their working limits.

2. Development of design matrix.

3. Measurement of the angular distortion

4. Development of mathematical model.

5. Adequacy check for the developed model.

6. Interpretation of results.

7. Conclusions of the research.

\subsection{Identification of input parameters and determining their working limits}

With the help of preliminary experimentations and an extensive literature survey, the following input parameters of WS, WFR, $\theta, \mathrm{V}$ and NPD were identified to have a significant effect on the angular distortion. For determination of the working limits trial runs were conducted by changing the numerical values of one of the five input parameters and keeping the other four as constant. The working limits were fixed by observing the weldments for -

- No visible signs of porosity.

- No spatters.

- No visible cracks, undercut or burn-through.

The process parameters were taken at five levels. The respective values for each level are shown in Table 3 .

\begin{tabular}{|c|c|c|c|c|c|c|}
\hline \multirow{2}{*}{ Welding Variables } & \multirow{2}{*}{ Units } & \multicolumn{5}{|c|}{ Limits } \\
\cline { 3 - 7 } & & -2 & -1 & 0 & 1 & 2 \\
\hline Wire Feed Rate & $\mathrm{m} / \mathrm{mins}$ & 0.3 & 0.6 & 0.9 & 1.2 & 1.5 \\
\hline Welding Speed & $\mathrm{cm} / \mathrm{mins}$ & 30 & 35 & 40 & 45 & 50 \\
\hline Arc Voltage & volts & 14 & 16 & 18 & 20 & 22 \\
\hline Nozzle to plate distance & $\mathrm{mm}$ & 10.0 & 12.5 & 15.0 & 17.5 & 20.0 \\
\hline Electrode to work angle & degrees & $70^{\circ}$ & $80^{\circ}$ & $90^{\circ}$ & $100^{\circ}$ & $110^{\circ}$ \\
\hline
\end{tabular}

Table 3. Welding variables and their limits

\subsection{Development of design matrix}

Sampling technique of CCRD technique was used to develop the model which resulted in 32 experimental runs, consisting of five input parameters, each at different five levels Lower limits are coded as -2 and upper limits are coded as +2 , Table 4 .

\subsection{Measuring the Angular Distortion-}

A height gauge fitted with a dial test indicator was used for the calculation of distortion in each plate. A small weight (as shown in Figure 3.) was put on one plate, making it touch the base plate and lifting the other plate by an angle equal to the angular distortion between the two plates. In order to set the zero count of height gauge, the probe of the dial test indicator touched to the flat plate. The height gauge is then moved and the slider of the height gauge is lowered till the tip of the dial test indicator plunger touches the edge of the lowered plate of the weldment giving height $h_{1}$. The weldment is now turned by $180^{\circ}$ and the same procedure is repeated to measure the height of the other edge as $h_{2}$. The average of $h_{1}$ and $h_{2}$ gives the raised height of the plates $h$. 


\begin{tabular}{|c|c|c|c|c|c|c|}
\hline Run & WFR & WS & $\mathbf{V}$ & NPD & $\begin{array}{c}\text { Torch } \\
\text { Angle }\end{array}$ & $\begin{array}{c}\text { Angular } \\
\text { Distortion }\end{array}$ \\
\hline & $\begin{array}{c}\mathbf{m} / \\
\mathbf{m i n}\end{array}$ & $\begin{array}{c}\mathbf{c m} / \\
\mathbf{m i n}\end{array}$ & $\mathbf{V o l t}$ & $\mathbf{m m}$ & $\begin{array}{c}\text { degre } \\
\mathbf{e}\end{array}$ & degree \\
\hline 1 & 1.2 & 45 & 16 & 12.5 & 100 & 3.77 \\
\hline 2 & 0.6 & 45 & 16 & 17.5 & 100 & 5.05 \\
\hline 3 & 0.9 & 40 & 18 & 15 & 90 & 3.91 \\
\hline 4 & 0.9 & 40 & 18 & 15 & 90 & 4.74 \\
\hline 5 & 0.6 & 35 & 16 & 17.5 & 80 & 3.47 \\
\hline 6 & 1.2 & 45 & 16 & 17.5 & 80 & 5.38 \\
\hline 7 & 1.2 & 35 & 16 & 12.5 & 80 & 4.55 \\
\hline 8 & 1.2 & 35 & 20 & 17.5 & 80 & 4.89 \\
\hline 9 & 0.9 & 40 & 18 & 15 & 110 & 2.25 \\
\hline 10 & 0.9 & 40 & 18 & 15 & 90 & 4.18 \\
\hline 11 & 0.6 & 45 & 20 & 17.5 & 80 & 6.14 \\
\hline 12 & 0.6 & 35 & 20 & 17.5 & 100 & 3.74 \\
\hline 13 & 0.9 & 40 & 14 & 15 & 90 & 4.13 \\
\hline 14 & 1.2 & 45 & 20 & 12.5 & 80 & 3.22 \\
\hline 15 & 0.9 & 30 & 18 & 15 & 90 & 5.35 \\
\hline 16 & 0.9 & 50 & 18 & 15 & 90 & 5.01 \\
\hline 17 & 1.5 & 40 & 18 & 15 & 90 & 5.44 \\
\hline 18 & 0.6 & 35 & 20 & 12.5 & 80 & 5.33 \\
\hline 19 & 0.9 & 40 & 18 & 15 & 90 & 4.28 \\
\hline 20 & 0.9 & 40 & 18 & 20 & 90 & 6.89 \\
\hline 21 & 0.9 & 40 & 18 & 15 & 90 & 4.28 \\
\hline 22 & 0.3 & 40 & 18 & 15 & 90 & 3.99 \\
\hline 23 & 0.6 & 45 & 20 & 12.5 & 100 & 3.97 \\
\hline 24 & 0.6 & 45 & 16 & 12.5 & 80 & 3.87 \\
\hline 25 & 1.2 & 35 & 20 & 12.5 & 100 & 3.01 \\
\hline 26 & 0.9 & 40 & 18 & 10 & 90 & 5.09 \\
\hline 27 & 0.6 & 35 & 16 & 12.5 & 100 & 4.63 \\
\hline 28 & 1.2 & 45 & 20 & 17.5 & 100 & 6.34 \\
\hline 29 & 0.9 & 40 & 22 & 15 & 90 & 3.75 \\
\hline 30 & 0.9 & 40 & 18 & 15 & 70 & 2.9 \\
\hline 31 & 0.9 & 40 & 18 & 15 & 90 & 4.28 \\
\hline 32 & 1.2 & 35 & 16 & 17.5 & 100 & 4.5 \\
\hline
\end{tabular}

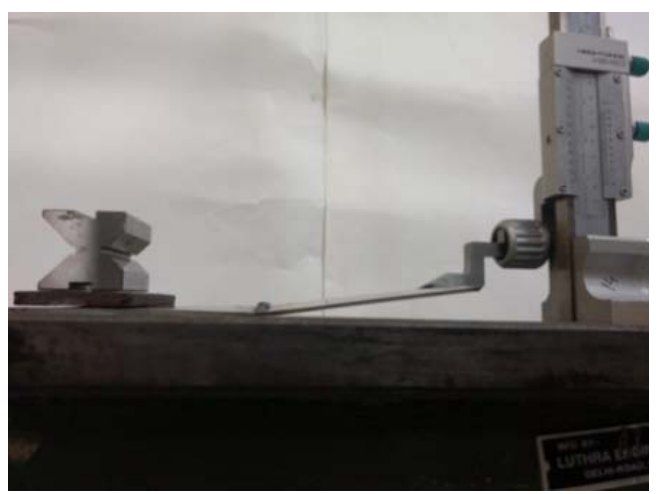

Fig. 3. Measurement of angular distortio

The relation, $\sin \theta=\frac{h}{l}$ was used to calculate the angular distortion, where $l$ being the thickness of the plate.

\subsection{Development of mathematical model-}

The angular distortion can be related to the five input parameters in form of an equation, as shown below:

Angular distortion $=f(A, B, C, D, E)$

where $\mathrm{A}-W F R$; $\mathrm{B}-W S$; C- $V$; D- NPD; E- $\theta$

A generalized form of mathematical equation can be written in the following form. This relates the input parameters to the angular distortion (response):

$\mathrm{x}=\beta \mathrm{o}+\beta_{1} \mathrm{~A}+\beta_{2} \mathrm{~B}+\beta_{3} \mathrm{C}+\beta_{3} \mathrm{D}+\beta_{3} \mathrm{E}+\beta_{12} \mathrm{AB}+\beta_{13} \mathrm{AC}$ $+\beta_{14} \mathrm{AD}+\beta_{15} \mathrm{AE}+\beta_{23} \mathrm{BC}+\beta_{24} \mathrm{BD}+\beta_{25} \mathrm{BE}+\beta_{34} \mathrm{CD}+$ $\beta_{35} \mathrm{CE}+\beta_{45} \mathrm{DE}+\beta_{11} \mathrm{~A}^{2}+\beta_{22} \mathrm{~B}^{2}+\beta_{33} \mathrm{C}^{2}+\beta_{44} \mathrm{D}^{2}+\beta_{55} \mathrm{E}^{2}$ Where $\beta_{1}, \beta_{2}, \beta_{11}, \beta_{12} \ldots$ are the regression coefficients.

Angular Distortion $=4.29+0.0983 A+0.1225 B+$ $0.0275 C+0.4483 D-0.1308 E-0.0062 A B-0.1812 A C$ $+0.3725 A D+0.0625 A E+0.1113 B C+0.5625 B D+$ $0.18 B E+0.25 C D-0.2 C E+0.0837 D E+0.102 A^{2}+$ $0.2183 B^{2}-0.0917 C^{2}+0.4208 D^{2}-0.433 E^{2}$

Table 4. Experimental Values of Angular distortion

\begin{tabular}{|c|c|c|c|c|c|c|c|c|c|c|c|c|}
\hline \multirow[t]{2}{*}{ 宗突 } & \multicolumn{2}{|c|}{ 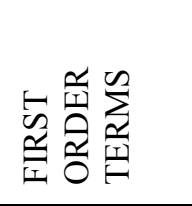 } & \multicolumn{2}{|c|}{ 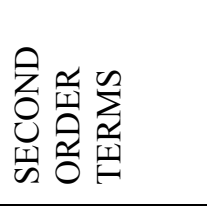 } & \multicolumn{2}{|l|}{ 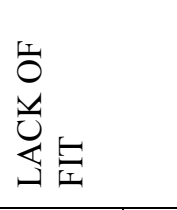 } & \multicolumn{2}{|l|}{ 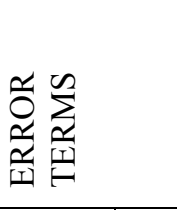 } & \multirow{2}{*}{ 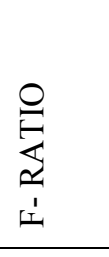 } & \multirow[b]{2}{*}{$\approx$} & \multirow[t]{2}{*}{ 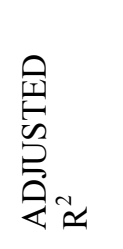 } & \multirow[t]{2}{*}{ 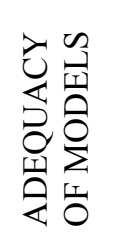 } \\
\hline & SS & $\mathrm{df}$ & SS & $\mathrm{df}$ & SS & df & SS & $\mathrm{df}$ & & & & \\
\hline $\begin{array}{l}\text { ANGULAR } \\
\text { DISTORTION }\end{array}$ & 5.8453 & 5 & 22.9825 & 15 & 1.5529 & 6 & 0.3585 & 5 & 8.599 & 0.9399 & 0.8306 & Adequate \\
\hline
\end{tabular}

\subsection{Adequacy check for the developed model}

ANOVA for the mathematical model developed shows the model to be significant and the lack of fit to be not significant for angular distortion. The high values of $\mathrm{R}^{2}$ also support the same.

\subsection{Interpretation of results}

\subsubsection{Direct effect of $V$}

With the increase in $\mathrm{V}$ it is observed that the Angular distortion increases. This shows that voltage increase leads to an increased the heat input per unit length, hence the thermal angular distortion increases. This is also evident in the figure shown below.

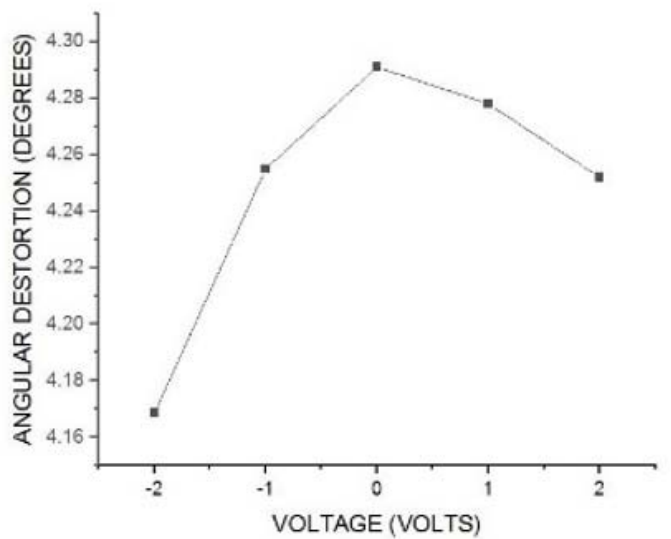

Fig. 4. Direct effect of Voltage 


\subsubsection{Direct effect of WFR}

In a constant voltage setup, as the WRF increases, current increases so that the length of arc is constant. The increase in current increases the heat input to the weld pool, which increase the angular distortion.

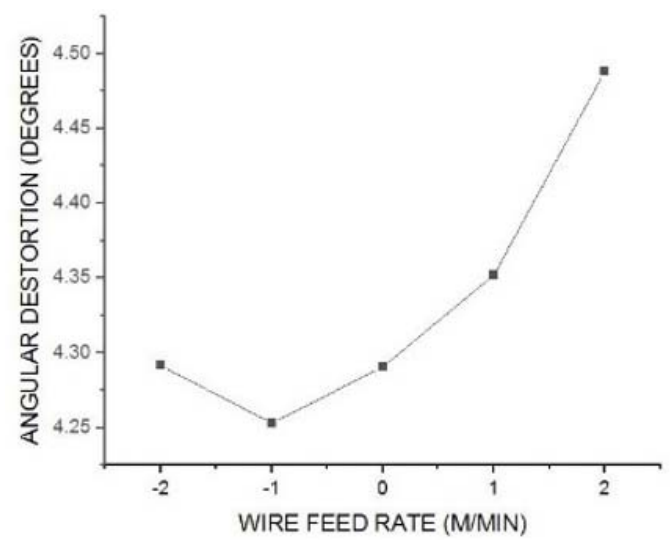

Fig. 5. Direct effect of WFR

\subsubsection{Direct effect of NPD}

As the NPD increases, length of unmelted wire between the nozzle tip and the arc increases, but the arc length remains constant (due to constant voltage). This causes more resistance to the path of current, thereby generating more heat between the nozzle and arc. This causes more wire to melt and go into the weld pool, thereby increasing the angular distortion.

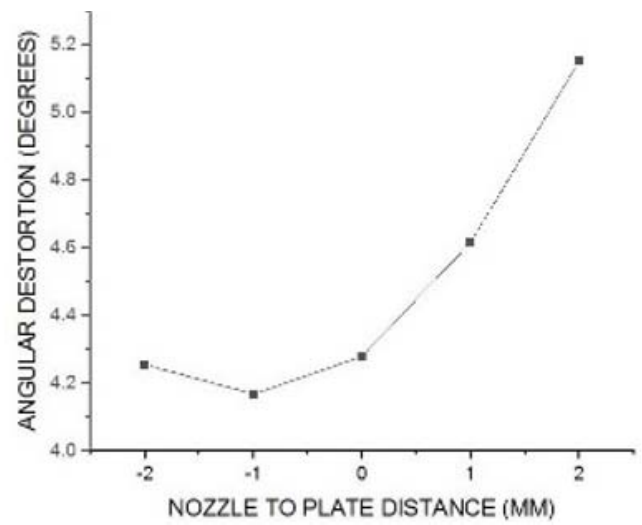

Fig. 6. Direct effect of Noyyle plate distance

\subsubsection{Direct effect of $\Theta$}

With the increase in $\theta$, the spread of the arc increases. This decreases the heat input per unit area, thereby decreasing the angular distortion.

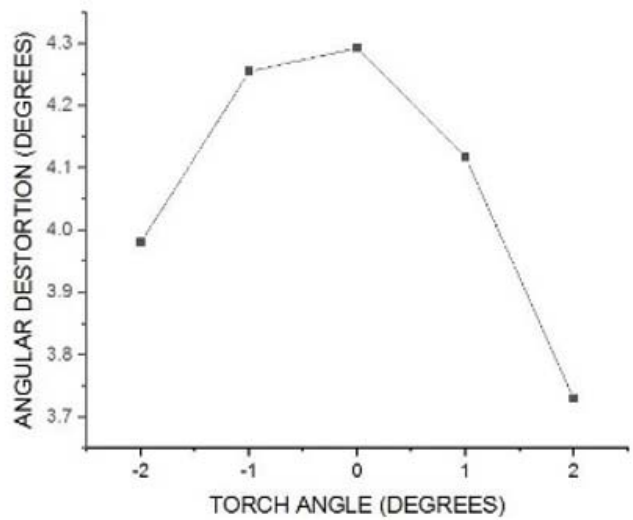

Fig. 7. Direct effect of Torch angle

\subsubsection{Interaction effect of NPD and WFR}

It is evident from the figure below that the maximum angular distortion is observed with maximum value of both NPD and WFR. This can be understood by the fact that as NPD increases, the filler wire length also increases and so the resistance in the path of current. This leads to an increase in the heat generated at the weld pool which ultimately translates into angular thermal distortion. Whereas, minimum value is obtained at maximum WFR and minimum NPD.

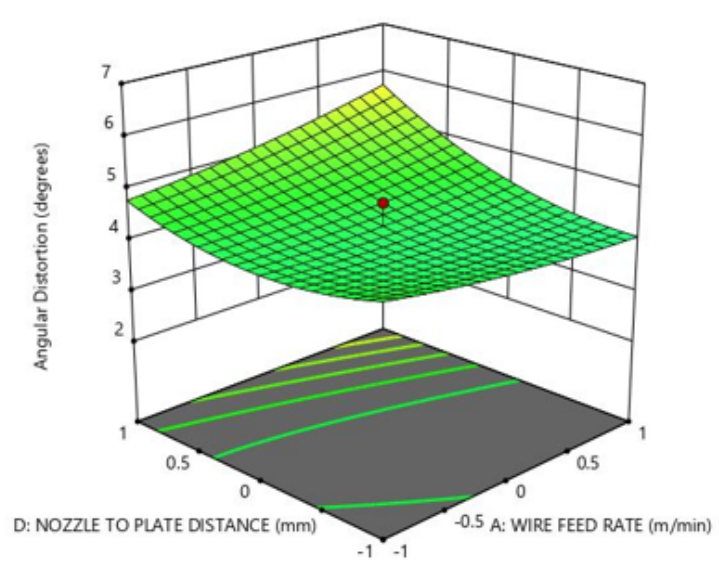

Fig. 8. Interaction effect of NPD and WFR

\subsubsection{Interaction effect of NPD and WS on Angular Distortion}

It is evident from the figure that maximum angular distortion is observed with maximum value of both NPD and WS. Whereas, minimum value is obtained at maximum NPD and minimum WS. This is attributed to the fact that as WS increases, the torch spends less time over each point in the butt joint, thus minimizing the excessive thermal heat at any given point and also with minimum NPD, the resistance to current in the filler wire is minimum, hence the least amount of thermal distortion.

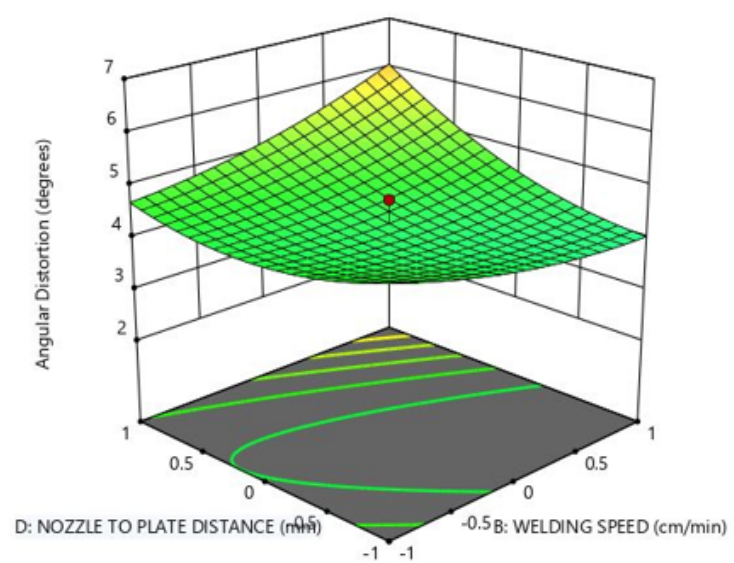

Fig. 9. Interaction effect of NPD and Welding Speed

\subsubsection{Interaction effect of NPD and $\Theta$ on Angular Distortion}

The given figure shows that NPD has a positive effect on Angular distortion, whereas $\theta$ has a negative one. Thus, maximum value is observed at maximum 
NPD and minimum $\theta$ and vice-versa. With increase in torch angle, the spread of the weld pool increases and thus the heat distribution also increases. This is the reason that minimum angular distortion can be observed at maximum torch angle and minimum NPD, where the resistance is minimum to the current in the filler wire.

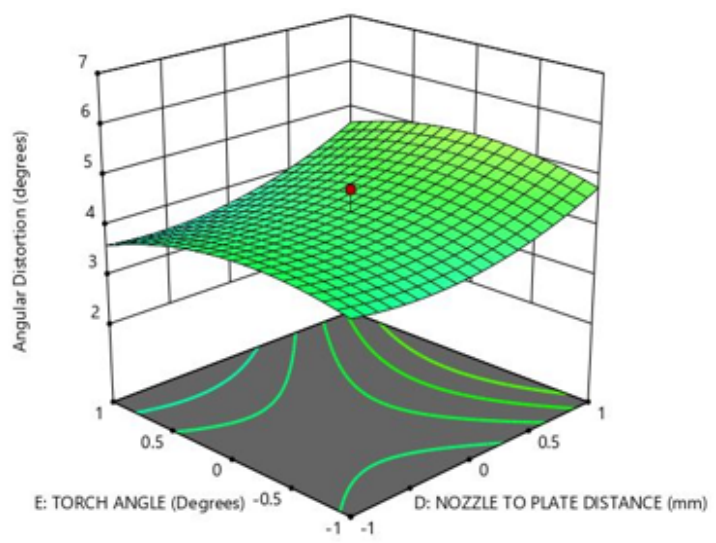

Fig. 10. Interaction effect of NPD and Torch angle

\subsubsection{Interaction effect of $V$ and $\Theta$ on Angular Distortion}

It can be observed from the given figure that $\mathrm{V}$ has a positive effect on Angular distortion, whereas $\theta$ has a negative one. Thus maximum value is observed at maximum $\mathrm{V}$ and minimum $\theta$ and minimum distortion at maximum $\mathrm{V}$ and minimum $\theta$. With an increase in $\mathrm{V}$, the heat generation increases and coupled with decreasing torch angle the weld pool spread further decreases, concentration the thermal energy for welding on a very small portion of the joint and thus limiting the heat affected zone, thereby increasing the angular distortion.

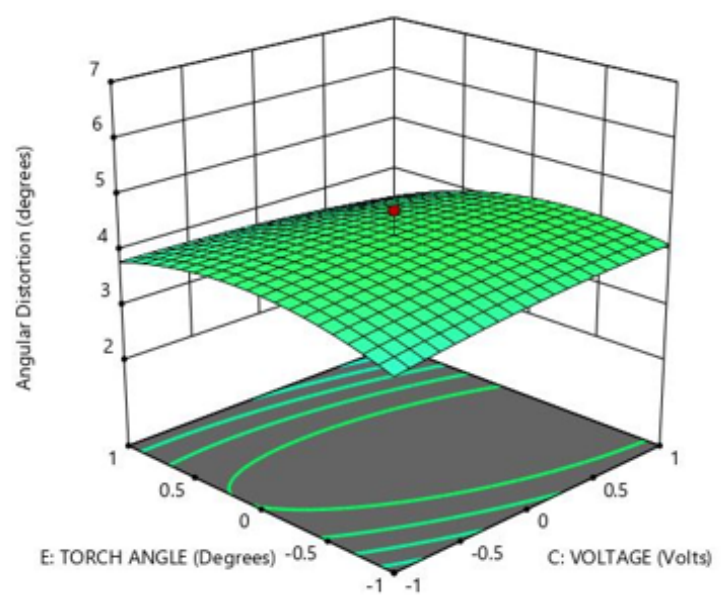

Fig. 11. Interaction effect of Voltage and Torch angle

\subsubsection{Interaction effect of WFR and V on Angular Distortion}

It is evident that WFR has a positive effect on Angular distortion, thus its minimum value is evident with minimum values of $\mathrm{V}$ and WFR and maximum at maximum WFR and minimum $V$. This can be understood from the facts that decreasing $\mathrm{V}$ leads to a reduction in the localized thermal energy generation and so does a decreasing WFR.

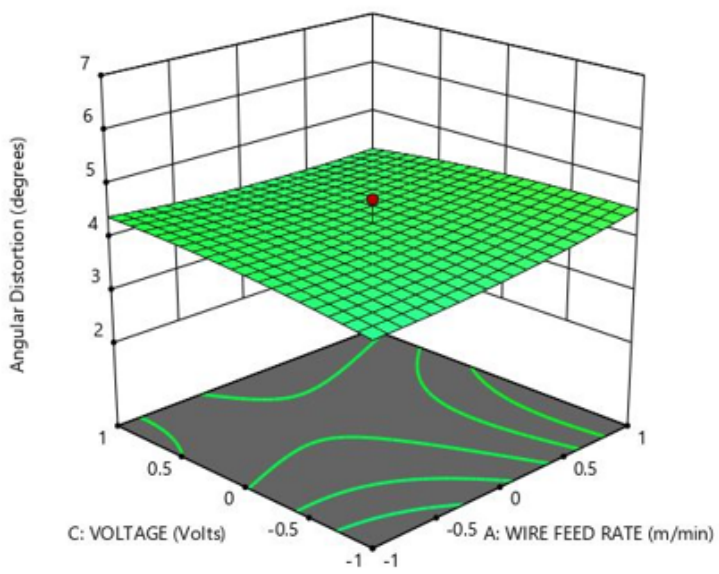

Fig. 12. Interaction effect of WFR and Voltage

\section{CONCLUSIONS}

1. For the development of mathematical models to predicting the weld bead dimensions, the technique of CCRD is found to be a useful and satisfactory tool.

2. An increase in angular distortion is observed due to increase in V, WS, WFR and NPD.

3. With the increase in $\Theta$, angular distortion decreases.

4. No defects were found in any weldments.

\section{REFERENCES}

[1] Kalpakjian, S, "Manufacturing Engineering and Technology", Pearson Publication, 2018

[2] Ye Z. Analysis of Welding Distortion Using Qualitative and Semi-Quantitative Techniques. The University of British Columbia; Vancouver, BC, Canada: 1998

[3] Wang R., Rashed S., Serizawa H., Murakawa H., Zhang J. Study on welding inherent deformations in welded structural materials. Trans. JWRI. 2008;37:91-100.

[4] Tseng K.H., Chou C.P. The study of nitrogen in argon gas on the angular distortion of austenitic stainless steel weldments. J. Mater. Process. Technol. 2003

[5] Jeong-Ung P., Gyubaek A., Lee H. Effect of external load on angular distortion in fillet welding. Mater. Des. 2012;42:403-410.

[6] Xie, D. and Zhao, J., "Cause of Angular Distortion in Fusion Welding: Asymmetric Cross-Sectional Profile along Thickness"

[7] Khanna, P., "Development of Mathematical Models for Prediction and Control of Weld Bead Dimensions in MIG Welding of Stainless Steel 409M", Science Direct, 2018

Authors: Vinayak Mehra, Student, Varun Gupta, Student, Pradeep Khanna, Associate Prof., Division of MPAE, Netaji Subhas University of Technology, New Delhi-110078, India.

E-mail: vinayak.mehra@gmail.com varungupta515@gmail.com 4.khanna@gmail.com 